\title{
Proyecto cultural La Moviola. Retrato de la metamorfosis de un cineclub
}

\author{
Andrés Romero Baltodano \\ Director proyecto cultural La Moviola
}

Hay personas a las que les gusta ver llover, a otros les parece fabuloso probar diversos tipos de chiles, a otros les llena la danza o incluso abominaciones, como la cacería de animales indefensos y las corridas de toros.

El arte no es como muchos piensan: una manera de usar el tiempo "chatarra" que les deja a muchos sus obligaciones laborales o económicas; el arte es tal vez alguna de las vías que tiene un humano de entender, fuera de su entorno y de sí mismo, una serie de sensaciones, que van, desde preguntas filosóficas, hasta conocimientos abruptos de realidades o surrealidades o infinitos momentos de una sensación de placer o miedo que es inenarrable.

Los que buceamos en el arte como un territorio de lúdicas, conocimientos y reflexiones siempre estamos intentando que un gran porcentaje de la población pruebe a acercarse a este inmenso mundo y permita que sus propias miradas o pensamientos puedan estar en constante debate (nada peor que un humano formateado igualito durante sus etapas de vida).

El Cineclub La Moviola comenzó cumpliendo con las funciones de un cineclub que inicialmente lleva a los espectadores a la sala de proyección y que acerca a los humanos a películas de corto o largometraje, a documentales o animaciones. Este cineclub en su largo transcurrir, además de su programación natural y semestral, ha comprendido que, en tiempos contemporáneos, 
también podría asumir otros papeles de complemento conceptual y académico no solo alrededor del cine, sino alrededor de lo que comprende al cine: el arte.

Por lo tanto, hemos realizado la curaduría que complementa, desde lo cinematográfico, la Cátedra Jaime Michelsen Uribe desde su creación, y hemos desarrollado un servicio denominado La Moviola Express que ofrece asesoría cinematográfica para la comunidad de docentes, quienes nos consultan sobre apoyos cinematográficos para sus clases, para trabajos externos o de investigación que comprometan el cine.

Por esto, nosotros como cineclubistas estamos del lado de quien posibilita el hecho de poder ver películas que nunca pasarían por una sala de explotación comercial y que hacen parte de la inmensa producción de películas, que se vienen dando hace 117 años en todos los rincones del planeta (un sueño de La Moviola es poder proyectar, al menos, una película de cada país del mundo). También entramos, en el territorio de la producción, desarrollando La Moviola Audiovisual, donde realizamos videoarte; un programa para televisión, donde entrevistamos al fotógrafo Werner Herzog; la serie de clips de difusión literaria ¿Sabes quien está aquí?, en asocio con la Biblioteca María Cristina Niño de Michelsen; y dos series de fotoclips: Francobturador (serie de fotógrafos del mundo) y Lapizarium (serie de ilustradores del mundo).

Otra labor que venimos cumpliendo es acercar el tema docente a la exhibición de material audiovisual con criterio académico y pedagógico en el ciclo alterno a nuestra programación habitual: La Escuela en el Cine, que, en asocio a la Decanatura del Medio Universitario, permite la proyección y el foro-debate con estudiantes y docentes sobre temas que tienen que ver directamente con la docencia, la pedagogía, el papel de la escuela en la sociedad, la escuela y la participación de género y diversidad.

Y como no solo somos audiovisual, la parte de complemento académico y cultural también ha sido fundamental en este proyecto cultural global: la publicación web de nuestra Revista Alternativa Multicultural Blog La Moviola que, a lo largo de sus ochenta ediciones, ha venido cumpliendo un papel fundamental alrededor del periodismo cultural y del tratamiento de temas, como la fotografía, el videoarte, la literatura, la arquitectura, las artes plásticas, las artes escénicas, la historia, el 
feminismo, etc., creando una red de colaboradores locales habituales y otra red de corresponsales en el mundo que nos han escrito desde Roma, Buenos Aires, Bruselas, Fortaleza, Barcelona, México, y otras ciudades, artículos que bucean y permiten llevar a nuestros lectores información y análisis de fenómenos que suceden allende nuestras fronteras. Nuestros colaboradores, siempre atentos e inquietos, llegan con sus colaboraciones para cada edición con temas que han hecho de nuestro archivo un riquísimo acervo cultural. Escribimos desde Colombia y, por ello, también nuestro mundo artístico próximo hace presencia en nuestras ediciones número a número.

La Revista Alternativa Multicultural Blog La Moviola siempre ha buscado la información que los grandes medios nunca publican, hace eco a artistas y expresiones atemporales en la medida que no es nuestra labor la actualidad, sino la información y análisis sobre arte, que cubre incluso la publicación de obra fotográfica, literaria, ensayística o de ilustración de artistas que la usan como una generosa ventana de exhibición.

A lo largo de estos ochenta números, también hemos realizado entrevistas exclusivas a íconos del cine, como Bruno Dumont o Guisseppe Rottuno; a actrices de cabaré político, como la mexicana Astrid Hadad; a directoras de cine, como Anna Negri o Albertina Carri.

Hemos recogido palabras en conversatorios con críticos de arte, como Hal Foster; directoras de cine, como Lucrecia Martel; directores de teatro, como Danile Finzi; cineastas colombianas, como Martha Rodríguez.

Estos ochenta números no hubieran sido posibles sin la cálida y maravillosa colaboración de grupos de estudiantes volantes comprometidos con el proyecto que cada semestre integran el grupo de apoyo y trabajo del proyecto cultural La Moviola; de las directivas de la Facultad de Mercadeo, Comunicación y Artes, en cabeza de su decano Sergio Hernández Muñoz; del director del Departamento de Medios Audiovisuales, Harvey Murcia Quiñones; de algunos profesores entusiastas, quienes han pasado por nuestras "páginas" digitales; de la Agencia Trompo, en cabeza de Ana Milena Cortés Moncada y su maravilloso equipo de estudiantes colaboradores; de la Decanatura del Medio Universitario, en cabeza de Carlos Augusto García; de Polimedios, en cabeza de Juan Germán de la Concha, a quienes les 
decimos de todo corazón "moviolo", muchas gracias.

Seguimos adelante día a día llevando este ambicioso proyecto cultural de La Moviola y queremos que los que ya conocen nuestra revista digital recuerden algunos artículos, y quienes hasta ahora se asoman al "mundo" de La Moviola lo hagan con la seguridad de encontrar un gran océano de información y referentes, que no solo son fundamentales desde lo académico, sino desde el goce fundamental de leer sobre arte.
La selección de artículos que leerán a continuación (dos ya publicados y uno de próxima publicación) trata de dar una pequeña muestra de nuestro arduo trabajo, y se realizó pensando en la pluralidad temática. Por su parte, quedan cientos de artículos alojados en nuestro sitio web http://lamoviolacineclub.blogspot.com/ esperándolos.

Por ahora, los invitamos a que caminen lentamente por el "abismo de las letras". Estamos seguros de que no se arrepentirán. 